\title{
Comparative study of viral encephalopathy and retinopathy in juvenile sea bass Dicentrarchus labrax infected in different ways
}

\author{
S. Péducasse*, J. Castric, R. Thiéry, J. Jeffroy, A. Le Ven, F. Baudin Laurencin \\ CNEVA Brest, Laboratoire de pathologie des animaux aquatiques - Technopôle Brest-Iroise, BP 70, F-29280 Plouzané, France
}

\begin{abstract}
The transmission of viral encephalopathy and retinopathy (VER) was investigated in juvenile sea bass ( $3 \mathrm{~g}$ ) Dicentrarchus labrax by using cell culture supernatant (SSN-1 cell line) containing nodavirus. Five methods of infection were tested: intramuscular injection (IM), intraperitoneal injection (IP), oral infection, bath exposure and cohabitation of healthy fish with infected fish. Some differences were observed in time of disease onset and severity of symptoms depending on the mode of infection used. Clinical symptoms such as whirling swimming and lethargic or hyperactive behaviour were generally reproduced, except for fish infected via oral and IP infection. First mortalities occurred $3 \mathrm{~d}$ after IM and IP infection and $6 \mathrm{~d}$ after for the other modes of infection. Cumulative mortalities were also variable: $100 \%$ after IM infection, $10 \%$ after IP infection, $32 \%$ for bath exposure, $43 \%$ after cohabitation and $24 \%$ via oral infection. Histopathologically, vacuolation was observed in the central nervous tissues and in the retina. The observed lesions were more or less severe depending on the mode of infection, the sampling time and the organs: lesions on the surviving fish (42 days post infection, $d$ p.i.) seemed to be generally more conspicuous in the retina than in the brain of the same fish. In most cases, the presence of nodavirus was confirmed in the same samples of brain and retina by immunohistochemistry and reverse transcriptase-polymerase chain reaction (RT-PCR). The virus was not detected in other organs examined. The present results suggest that 2 forms of VER can be induced: IM injection leads to an acute form (severe nervous disorders with high and fast mortality) whereas oral infection, bath exposure and cohabitation induce a subacute form (less severe disorders and weak daily mortality). This experiment demonstrates experimentally induced horizontal transmission of VER in sea bass for the first time.
\end{abstract}

KEY WORDS: Sea bass - Viral encephalopathy and retinopathy - Nodavirus - Transmission Immunohistochemistry $\cdot$ RT-PCR

\section{INTRODUCTION}

Since 1985, a new disease, recently named viral encephalopathy and retinopathy (VER) by the OIE (Office International des Epizooties 1995) has appeared in approximately 25 species of cultured marine fish: sea bass Dicentrarchus labrax (L.) in Martinique (Bellance \& Gallet de Saint Aurin 1988) and in France (Breuil et al. 1991), barramundi Lates calcarifer (Bloch) (Glazebrook et al. 1990, Renault et al. 1991), halibut Hippoglossus hippoglossus (L.) (Grotmol et al. 1995),

\footnotetext{
•E-mail: speducas@brest.cneva.fr
}

turbot Scophthalmus maximus (L.) (Bloch et al. 1991) and numerous species in Japan such as Oplegnathus fasciatus (Temminck \& Schlegel) (Yoshikoshi \& Inoue 1990), striped jack Pseudocaranx dentex (Bloch \& Schneider) (Mori et al. 1992, Arimoto et al. 1994), and redspotted grouper Epinephelus akaara (Temminck \& Schlegel) (Mori et al. 1991). The disease mainly occurs in larval and juvenile stages of marine fish and frequently leads to high mortalities. Fish generally show abnormal swimming behaviour and, histopathologically, the disease is characterised by conspicuous vacuoles in the nervous tissues of different parts of the brain and the retina. Electron microscopy reveals, viral particles of 25 to $30 \mathrm{~nm}$ in the cytoplasm of affected 
cells. Different methods such as immunohistochemistry (Le Breton et al. 1997) and polymerase chain reaction (Nishizawa et al. 1994) are used to detect the presence of virus or viral genome in fish organs. Some studies have already been done on the transmission of the disease: Glazebrook et al. (1990) experimentally demonstrated the possibility of horizontal transmission from diseased barramundi larvae to healthy ones. Mori et al. (1991) and Arimoto et al. (1993) reported transmission of the disease to redspotted grouper juveniles and to striped jack larvae exposed to a bath of filtered homogenates from diseased fish. Arimoto et al. (1993) were also able to transmit the disease by cohabitation of diseased and healthy larvae. A few studies have been carried out with juvenile fish: Boonyaratpalin et al. (1996) succeeded in transmitting the disease to juvenile of Epinephelus malabaricus (Bloch \& Schneider). Preliminary experiments were also conducted on E. septemfasciatus and E. akaara (Tanaka et al. 1998) and on juvenile sea bass D. labrax (Thiéry et al. 1997) using intramuscular injection of brain and eye hornogenates from diseased fish. As VER became a threat for hatchery production of sea bass larvae and juvenile, the experimental model of horizontal transmission was refined to study the pathogenicity of the virus and the epidemiology of the disease. Subsequently, the aim of the present work is to verify the possibility of horizontal transmission of VER to juvenile sea bass, to test and to compare different routes of infection by using 2 methods for detecting the virus.

\section{MATERIALS AND METHODS}

Fish and installation. Sea bass used in the experiment were juvenile weighing $3 \mathrm{~g}$ and came from a Mediterranean fish breeding never previously affected with VER. Fish were randomly placed in $50 \mathrm{l}$ (volume of water: 30 l) aerated tanks, with opened circulation of sea water filtered and sterilised by UV at a controlled temperature of $25 \pm 1^{\circ} \mathrm{C}$. A commercial food was manually distributed twice a day.

Virus preparation. Brains and eyes from sea bass suffering from VER were homogenised in a mortar with pestle and sea sand and with 9 volumes of Eagle's solution containing penicillin (200 immunising units [I.U.] $\left.\mathrm{ml}^{-1}\right)$, streptomycin $\left(0.2 \mathrm{mg} \mathrm{ml}^{-1}\right)$ and kanamycin $\left(0.2 \mathrm{mg} \mathrm{ml}^{-1}\right)$. After centrifugation at $2000 \times \mathrm{g}$ for $15 \mathrm{~min}$ at $4^{\circ} \mathrm{C}$, the supernatant was passed through a membrane filter $(0.45 \mu \mathrm{m})$ and was inoculated on SSN-1 cells (Frerichs et al. 1996). The cells were grown in Leibovitz medium (L15) supplemented with $10 \%$ foetal bovine serum, penicillin 100 I.U. $\mathrm{ml}^{-1}$, streptomycin $0.1 \mathrm{mg} \mathrm{ml}^{-1}$. Inoculated cells were incubated at $24^{\circ} \mathrm{C}$ for 4 or $5 \mathrm{~d}$. The strain (V26) was passed 3 more times on cell culture before being used in experiments. The cell culture supernatant was recovered and the cellular debris was removed by centrifugation at 2000 $\times g$ for $15 \mathrm{~min}$ at $4^{\circ} \mathrm{C}$. Aliquots of the viral suspension were stored at $-80^{\circ} \mathrm{C}$ until used.

Virus titration was conducted on preformed monolayers of SSN-1 cells in a 24 well-plate using serial 10 fold dilutions from $10^{-1}$ to $10^{-10}$ of cell culture supernatant. Cultures were then incubated at $24^{\circ} \mathrm{C}$ for $5 \mathrm{~d}$. As the cytopathic effect was not always clearly obtained, the nodavirus was identified on cell culture by an indirect immunofluorescence technique (IFAT). Briefly, cell monolayers were fixed with ethanolacetone and then treated for an hour at $37^{\circ} \mathrm{C}$ with a rabbit polyclonal serum against sea bass nodavirus. After washing with phosphate-buffered saline (PBS) Tween, the plate was incubated for an hour at $37^{\circ} \mathrm{C}$ with an anti-rabbit Ig goat antibody conjugated with FITC (fluorescein isothiocyanate) (Sigma). Virus titration was defined by the last detection of virus after IFAT treatment in the 10 -fold dilutions. Infection experiments were performed with cell culture supernatant with an initial infectivity titre of $10^{7}$ plagueforming unit (PFU) $\mathrm{ml}^{-1}$.

Infection protocol. For oral infection, 40 fish were fed with food mixed with $1 \mathrm{ml}$ of V26 cell culture supernatant. A total of $6 \mathrm{~g}$ of food per day was manually distributed for $5 \mathrm{~d}$ in small amounts to avoid the decomposition of unused food granules in water and to control the food ingestion by fish. In bath exposure, $1 \mathrm{ml}$ of $\mathrm{V} 26$ was added to $20 \mathrm{l}$ of water. Forty fish were placed in this tank at $25^{\circ} \mathrm{C}$ for $2 \mathrm{~h}$ under aeration; normal water circulation was then restored. Forty fish were infected by intramuscular injection of $100 \mu \mathrm{l}$ of cell culture supernatant diluted to $1 / 10$. For a cohabitation experiment, 40 healthy fish marked with alcian blue injection were added to the tank containing the 40 intramuscularly infected fish. Another batch of 40 fish was infected by intraperitoneal injection of $100 \mu \mathrm{l}$ of cell culture supernatant diluted to $1 / 10$.

For each mode of infection, a mock-infected control group of 40 fish was handled in the same manner but the viral suspension was replaced by a non-infected cell culture supernatant.

Sampling and analysing protocol. At Days 2, 4 and 42 post-infection (p.i.). 5 fish from each infected group were randomly taken except for those infected by cohabitation for which samples were only taken at Days 4 and 42 p.i. The eyes, brain, gills, heart, spleen, liver, kidney, stomach and intestine of all fish were collected. The spinal cord was taken as frequently as possible. All the samples were analysed by histopathology, immunohistochemistry (IHC) and reverse transcriptase polymerase chain reaction (RT-PCR). At the end of experiment (Day 42 p.i.), all the survivors were 
collected and their brains and eyes were examined by histopathology, IHC and RT-PCR. Dead fish were collected every day and only brains and eyes were analysed by RT-PCR. At Day 42 p.i., 5 fish of each control group were randomly taken and their brains and eyes analysed by RT-PCR and histology.

Methods of virus detection. Histopathology and immunohistochemistry: Organ samples were fixed in Bouin's fixative, dehydrated through a graded ethanol xylene series and embedded in paraffin. Sections of 5 to $6 \mu \mathrm{m}$ were first deparaffinised, rehydrated and then were either stained with haematoxylin-eosin ( $\mathrm{H} \& \mathrm{E}$ ) for histopathological examination (Gabe 1968) or treated by IHC. The IHC detection of viral antigens was performed with a rabbit polyclonal serum against nodavirus coming from sea bass. Endogenous peroxidase activity was blocked by incubating the slides in a $3 \%$ solution of hydrogen peroxide in distilled water for $5 \mathrm{~min}$. After washing in PBS for $5 \mathrm{~min}$, nonspecific antibody sites were blocked by covering the sections with a solution of $2.5 \%$ BSA in PBS for 10 min, followed by incubation with rabbit polyclonal antiserum for $1 \mathrm{~h}$ at room temperature. After washing 2 times for $3 \mathrm{~min}$ with PBS Tween and 1 time with PBS, sections were incubated for 30 min with an anti-rabbit Ig goat antibody conjugated with peroxidase. After washing, the peroxidase substrate solution (AEC chromogene, Sigma) was added for $10 \mathrm{~min}$. After washing with distilled water, samples were counterstained with haematoxylin and mounted in an aqueous mounting medium. The presence of nodavirus antigens was characterised by a brown coloration.

A scale of intensity of IHC reaction was defined as follows: $(+)$ corresponding to a few marked cells in the tissue section (1 to 5$) ;(++)$ corresponding to 5-15 stained cells and $(+++)$ for more stained cells.

RT-PCR: Parts of the samples were treated for the detection of RNA 2 gene by RT-PCR according to the procedure previously described by Nishizawa et al. (1994). In this experiment, the T4 region was selected as a target sequence for amplification. The total RNA of each sample was isolated using RNA NOW (Biogenetex). Complementary DNA was then synthesised from extracted RNAs by using MuLV reverse transcriptase (Perkin Elmer) and a reverse primer R3 (5'-CGA GTC AAC ACG GGT GAA GA-3') (Genset). After addition of a forward primer F2 (5'-CGT GTC AGT CAT GTG TCG CT-3') (Genset) and Taq DNA polymerase to the mixture, each cycle of amplification. was repeated 40 times. Finally, $15 \mu \mathrm{l}$ of the PCR products were analysed by $1.5 \%$ agarose gel electrophoresis. A specific band of 420 base pairs (bp) was observed in case of successful amplification of the nodavirus genome.

\section{RESULTS}

\section{Clinical signs and mortalities}

The initial clinical sign of infection was a black skin pigmentation which rapidly appeared in fish that were intramuscularly and intraperitonealy injected (2 d p.i.) and later $(6 \mathrm{~d}$ p.i) in fish infected by the other modes (Table 1). In most cases, an abnormal behaviour was observed: some fish were lethargic and floated with their abdomen up or, on the contrary, displayed hyperexcitability when they were disturbed (artificial light, food distribution). Spiral swimming was often seen and seemed to lead to death of the fish. For these fish, the survival time varied from several hours to 3-4 d. After oral and IP infection, fish never showed erratic swimming. A few fish showed a swimbladder hyperinflation and afterwards they floated on the surface of water. This change was observed late in infection and only after bath exposure and cohabitation.

Table 1. Dicentrarchus labrax. Comparison of clinical signs and mortalities depending on the mode of infection

\begin{tabular}{|c|c|c|c|c|}
\hline \multirow[t]{2}{*}{ Mode of infection } & \multicolumn{2}{|c|}{ Clinical symptoms } & \multicolumn{2}{|c|}{ Mortalities } \\
\hline & First day outbreak & Observed signs & Beginning & End \\
\hline Oral contamination & Days 6-7 & $\begin{array}{l}\text { Dark colour, } \\
\text { hyperreactivity }\end{array}$ & $\begin{array}{l}\text { Day } 6 \\
(10 \%)\end{array}$ & $\begin{array}{l}\text { Day } 15 \\
(24 \%)\end{array}$ \\
\hline Bath exposure & Day 6 & $\begin{array}{l}\text { Dark colour, } \\
\text { whirling pattern of swimming, } \\
\text { swimbladder hyperinflation }\end{array}$ & $\begin{array}{l}\text { Day } 6 \\
(17 \%)\end{array}$ & $\begin{array}{l}\text { Day } 21 \\
(32 \%)\end{array}$ \\
\hline Cohabitation & Day 6 & $\begin{array}{l}\text { Dark colour, } \\
\text { whirling pattern of swimming, } \\
\text { swimbladder hyperinflation }\end{array}$ & $\begin{array}{l}\text { Day } 6 \\
(3 \%)\end{array}$ & $\begin{array}{l}\text { Day } 37 \\
(43 \%)\end{array}$ \\
\hline IM injection & Day 2 & $\begin{array}{l}\text { Dark colour, } \\
\text { whirling pattern of swimming }\end{array}$ & $\begin{array}{l}\text { Day } 3 \\
(56 \%)\end{array}$ & $\begin{array}{l}\text { Day } 4 \\
(100 \%)\end{array}$ \\
\hline IP injection & Day 2 & $\begin{array}{l}\text { Dark colour, } \\
\text { hyperreactivity }\end{array}$ & $\begin{array}{l}\text { Day } 4 \\
(7 \%)\end{array}$ & $\begin{array}{l}\text { Day } 5 \\
(10 \%)\end{array}$ \\
\hline
\end{tabular}



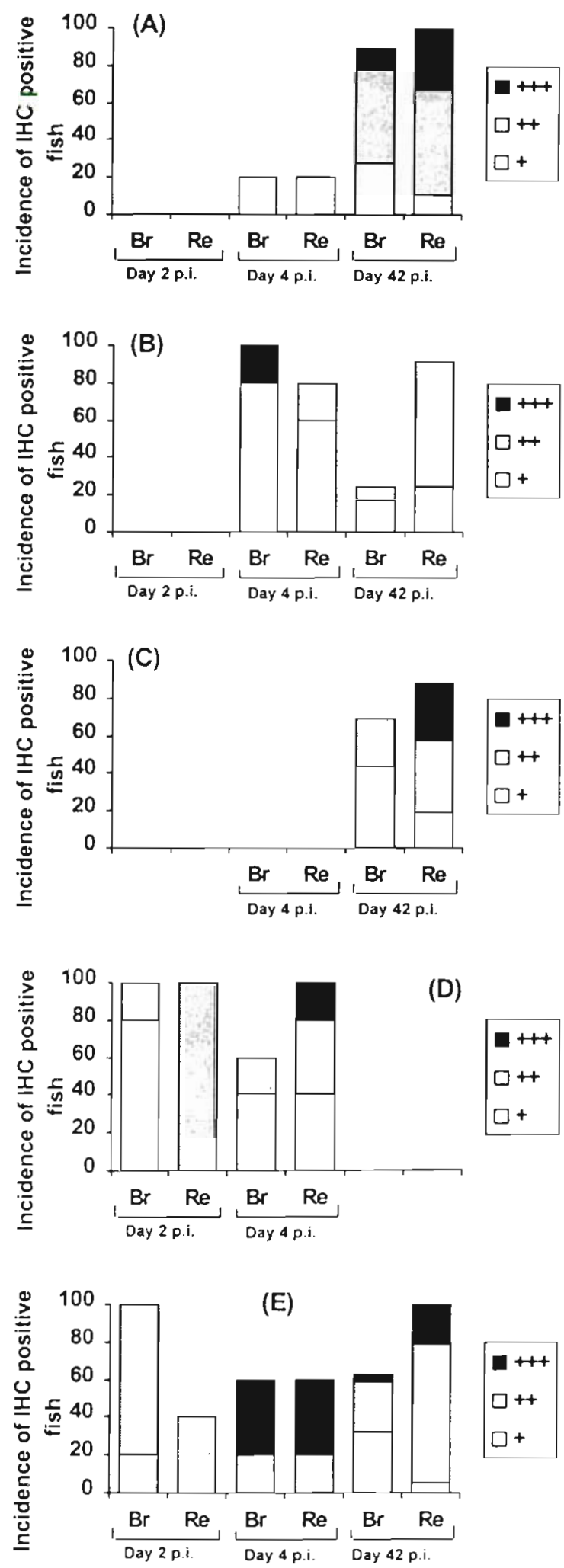

Fig. 1. Dicentrarchus labrax. IHC detection of nodavirus from 5 groups of infected sea bass juvenile. (A) Oral infection, (B) bath exposure, (C) cohabitation, (D) IM injection and (E) IP injection. Br brain, Re: retina, p.i.: post-infection. Intensity of IHC $(+)$ weak, $(++)$ moderate and $(+++)$ strong
Cumulative mortalities depended on the mode of infection. After IM injection, mortalities reached 100\% $4 \mathrm{~d}$ p.i. By oral infection, mortalities regularly extended from Day 6 to Day 15 p.i. to finally reach $24 \%$ at the end of experiment. After bath exposure, mortalities (32\%) were mainly limited to Day 6 and Day 7 p.i. In the cohabitation experiment, 2 main mortalities periods could be distinguished: the first one from Day 6 to Day 14 p.i. $(22 \%)$ and the second from Day 20 to Day 26 p.i. (40\%). By IP infection, mortalities (10\%) appeared 3 d p.i. but stopped rapidly.

\section{Histopathological, IHC and RT-PCR analysis}

Vacuolation and basophilic cells in the retina and brain, the most characteristic histopathological signs of VER, were reproduced in experimentally infected fish.

\section{Oral infection}

On Day 2 p.i., no conspicuous histopathological changes were seen in the brain, the retina or in other tissues in any examined fish (Table 2, Fig. 1A). This result was confirmed by the absence of detectable viral antigen or viral RNA, by IHC or RT-PCR analysis, respectively. At Day 4 p.i., 1 of the 5 fish was detected positive in the brain and 1 in the retina but the intensity of IHC reactions was weak. No lesions were seen at this stage of infection. At Day 42 p.i., $89 \%$ of fish were IHC positive in brain samples and all were positive in retina samples. For the same group of fish, RT- PCR analysis (Fig. 2) showed 56 and $78 \%$ of fish positive in the brain and retina, respectively. The intensity of IHC reaction varied considerably from fish to fish, but as a rule intensity was stronger in retina samples, particularly in the inner nuclear and ganglionic cell layers (Fig. 3). The brain and the spinal cord (observed as frequently as possible) were relatively spared by the virus with only few vacuoles; on the contrary, degeneration of nerve cells and vacuolation in the retina were often very advanced. Focal aggregates strongly stained by $\mathrm{H} \& \mathrm{E}$ and $\mathrm{IHC}$ were also observed (Fig. 4).

\section{Bath exposure}

At Day 2 p.i., no samples positive for IHC and RTPCR were detected and no lesions were noted in sampled organs (Table 2, Fig. 1B). At Day 4 p.i., 5 brains and 4 retina were positive by IHC. Basophilic cells strongly stained by H\&E were observed in the same sections. At Day 42 p.i., retina from most fish 
Table 2. Dicentrarchus labrax. Number of fish found IHC and RT-PCR positive in brain and retina samples (d p.i.: days postinfection; $N$ : number of tested fish)

\begin{tabular}{|c|c|c|c|c|c|c|c|c|c|c|c|c|c|c|}
\hline Tissue & Method & $\begin{array}{l}\text { Oral } \\
2 \mathrm{~d} \text { p.i. } \\
(\mathrm{N}=5)\end{array}$ & $\begin{array}{l}\text { contami } \\
4 \mathrm{~d} \text { p.i. } \\
(\mathrm{N}=5)\end{array}$ & $\begin{array}{l}\text { ination } \\
42 \mathrm{~d} \text { p.i. } \\
(\mathrm{N}=18)\end{array}$ & $\begin{array}{r}\quad \mathrm{Ba} \\
2 \mathrm{~d} p . \dot{i} . \\
(\mathrm{N}=5)\end{array}$ & $\begin{array}{l}\text { the exp } \\
4 \mathrm{~d} p . \mathrm{i} . \\
(\mathrm{N}=5)\end{array}$ & $\begin{array}{l}\text { osure } \\
42 \mathrm{~d} p . \dot{\mathrm{i}} \\
(\mathrm{N}=17)\end{array}$ & $\begin{array}{l}\text { Cohab } \\
4 \mathrm{~d} \text { p.i. } \\
(\mathrm{N}=5)\end{array}$ & $\begin{array}{l}42 \text { d p.i. } \\
(N=16)\end{array}$ & $\begin{array}{l}\text { IN } \\
d 2 p . j . \\
(N=5)\end{array}$ & $\begin{array}{l}4 \mathrm{~d} p . i . \\
(N=5)\end{array}$ & $\begin{array}{l}2 d \text { p.i. } \\
(N=5)\end{array}$ & $\begin{array}{c}\text { IP } \\
4 \mathrm{~d} p . i \\
(\mathrm{~N}=5)\end{array}$ & $\begin{array}{l}42 \mathrm{~d} p . i \\
(\mathrm{~N}=19)\end{array}$ \\
\hline Brain & $\begin{array}{l}\text { IHC } \\
\text { RT-PCR }\end{array}$ & $\begin{array}{l}0 \\
0\end{array}$ & $\begin{array}{l}1 \\
0\end{array}$ & $\begin{array}{l}16 \\
10\end{array}$ & $\begin{array}{l}0 \\
0\end{array}$ & $\begin{array}{l}5 \\
4\end{array}$ & $\begin{array}{l}6 \\
6\end{array}$ & $\begin{array}{l}0 \\
0\end{array}$ & $\begin{array}{l}11 \\
10\end{array}$ & $\begin{array}{l}5 \\
5\end{array}$ & $\begin{array}{l}3 \\
3\end{array}$ & $\begin{array}{l}5 \\
5\end{array}$ & $\begin{array}{l}3 \\
3\end{array}$ & $\begin{array}{r}12 \\
6\end{array}$ \\
\hline Retina & $\begin{array}{l}\text { IHC } \\
\text { RT-PCR }\end{array}$ & $\begin{array}{l}0 \\
0\end{array}$ & $\begin{array}{l}1 \\
0\end{array}$ & $\begin{array}{l}18 \\
14\end{array}$ & $\begin{array}{l}0 \\
0\end{array}$ & $\begin{array}{l}4 \\
4\end{array}$ & $\begin{array}{l}15 \\
11\end{array}$ & $\begin{array}{l}0 \\
0\end{array}$ & $\begin{array}{l}14 \\
12\end{array}$ & $\begin{array}{l}5 \\
4\end{array}$ & $\begin{array}{l}5 \\
5\end{array}$ & $\begin{array}{l}2 \\
2\end{array}$ & $\begin{array}{l}3 \\
3\end{array}$ & $\begin{array}{l}19 \\
18\end{array}$ \\
\hline
\end{tabular}

(15 out of 17 ) and brains from 6 fish were found to be IHC positive. IHC labeling was mainly observed in ganglionic cell and nerve fiber layers and to a lesser extent in the inner nuclear layer. Focal aggregates strongly stained by $\mathrm{H} \& \mathrm{E}$ and $\mathrm{IHC}$ reaction were also noted in the same layers. The intensity of IHC was generally moderate. Basophilic cells and vacuoles were often observed in retina whereas vacuoles were rare in the brain.

\section{Cohabitation}

At Day 4 p.i., no conspicuous histopathological changes were seen in the sampled organs and no virus was detected by IHC and RT-PCR examinations (Table 2, Fig. 1C). At Day 42 p.i., 11 and 14 fish out of 16 were diagnosed positive in the brain and retina, respectively. IHC labeling was pronounced $(+++)$ in the inner nuclear and ganglionic cell layers, but variable in the outer nuclear layer. The lesions were similar to those observed after oral infection and bath

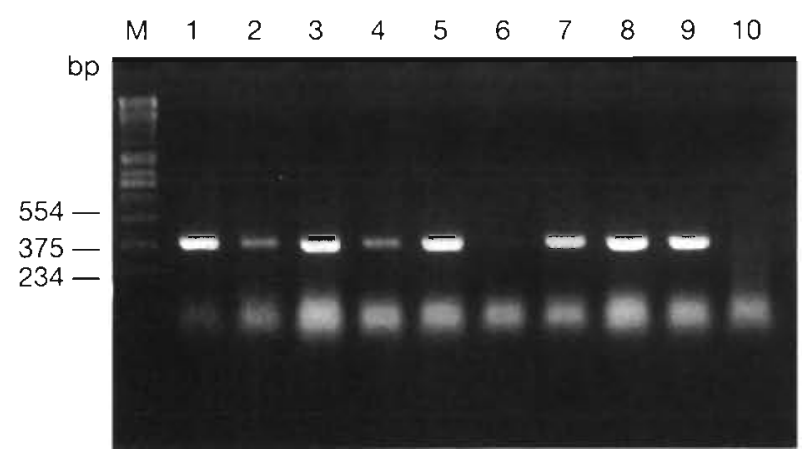

Fig. 2. Agarose gel stained with ethidium bromide of RT-PCR products $(420 \mathrm{bp})$. Detection of sea bass nodavirus gene from brain and eye of 4 fish after oral infection (Day 42 p.i.). M: DNA ladder (Raoul marker, Appligene); Lanes 1, 3, 5 , and 7 : products of RT-PCR from eye samples of infected fish; Lanes 2, 4, 6 and 8: products of RT-PCR from brain samples of infected fish; Lane 9: tissue samples (brain or eye) of fish known to be positive (RT-PCR positive control); Lane 10: eye sample of the control group (RT-PCR negative control) exposure. The brain showed only basophilic cells and moderate IHC labeling $(+$ or ++ ) whereas the retina displayed focal aggregates, vacuoles and often strong IHC labeling.

\section{IM injection}

At Day 2 p.i., all brain and retina samples were determined to be positive by IHC (Table 2, Fig. 1D). The spinal cord samples which were observed were also positive after IHC treatment (Fig. 5). In the same samples, basophilic cells and necrosis were observed by H\&E staining. At Day 4 p.i., 3 fish out of 5 and 5 out of 5 were positive in the brain and retina, respectively. IHC labeling was prominent in the nuclear and plexiform layers but also in the rod and cone cells of the retina (Fig. 6). Neuronal degeneration of the brain tissue was always less pronounced than retinal degeneration in the same fish.

\section{IP injection}

At Day 2 p.i., the brair. samples of all fish were diagnosed positive while the retina samples of 2 fish were positive. IHC labeling was also observed in the spinal cord (Table 2, Fig. 1E). At this stage, the IHC intensity was moderate $(+$ or ++ ) and no lesions were seen. At Day 4 p.i., 3 fish were found to be positive in the brain (Fig. 7) and retina upon IHC and RT-PCR examination. IHC labeling was conspicuous in the brain, in the ganglionic cell layer and in the inner and outer nuclear and plexiform layers of the retina. Conspicuous vacuoles were observed especially in the outer nuclear layer (Fig. 8) whereas few small vacuoles were seen in brain of the same fish. At Day 42 p.i., 12 brains out of 19 and all retinas were determined positive after IHC treatment. IHC labeling was in general less conspicuous than at Day 4 p.i. However, severe vacuolation and focal aggregates strongly stained by $H \& E$ were seen in all retinas and slight vacuolation was noted in the brain. 

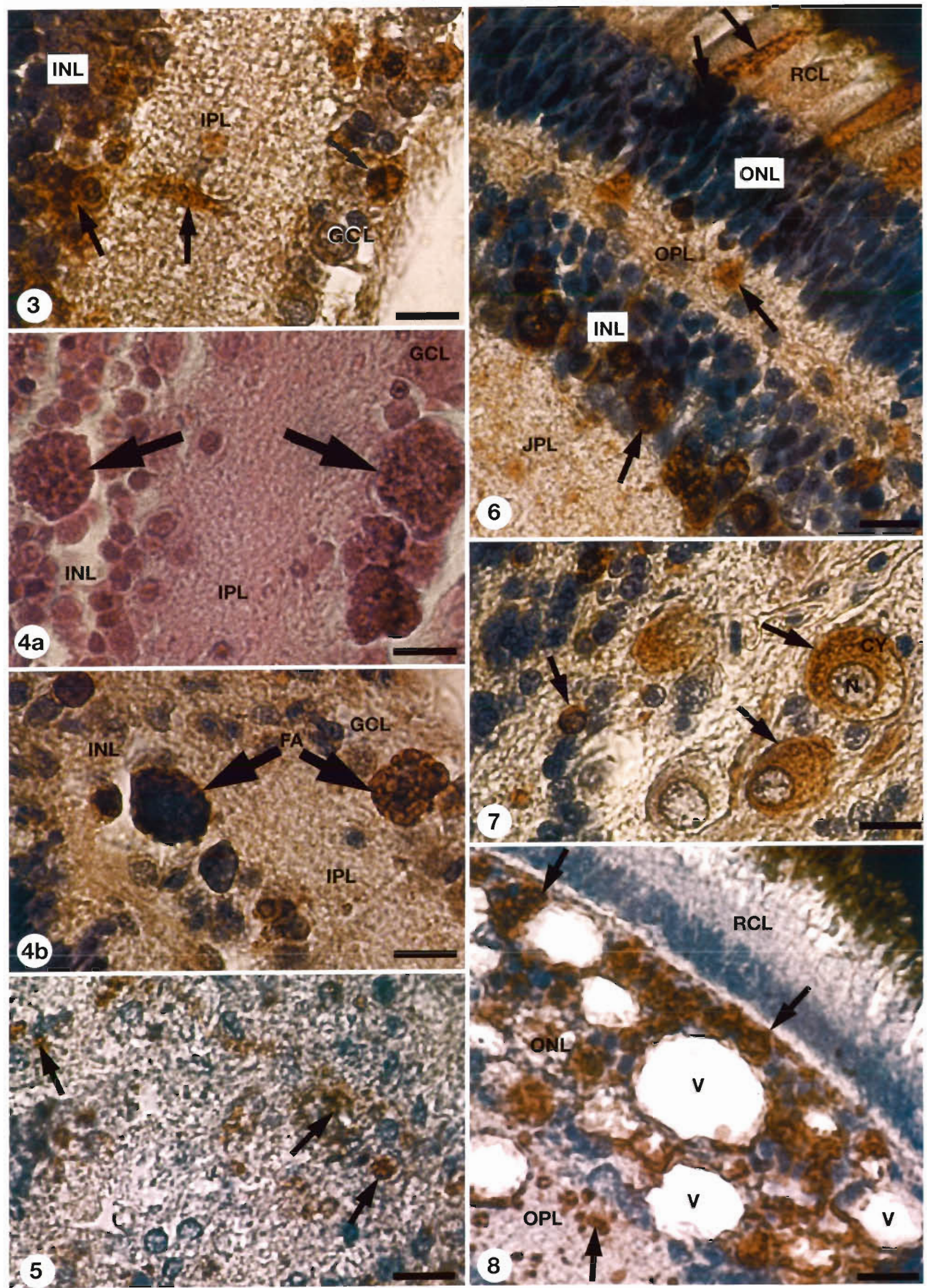
Figs. 3-8. Dicentrarchus labrax. Fig. 3. Section of eye stained immunohistochemically after oral infection (Day 42 p.i.). Note the immunolabeling in the inner nuclear layer (INL), in the ganglionic cell layer (GCL) and in the inner plexiform layer (IPL) of the retina (arrows). Scale bar $=10 \mu \mathrm{m}$. Fig. 4. (a) Section of eye after oral infection (Day 42 p.i.) stained with haematoxylin-eosin. Note the focal aggregates (arrows) strongly stained by haematoxylin-eosin in the inner nuclear layer (INL) and in the ganglionic cell layer (GCL) of the retina. Scale bar $=10 \mu \mathrm{m}$. (b) Eye stained immunohistochemically after oral infection (Day 42 p.i.). Note the focal aggregates (FA), as Fig. 3 strongly stained after IHC reaction (arrows) in the inner nuclear layer (INL) and in the ganglionic cell layer (GCL). IPL: inner plexiform layer. Scale bar $=10 \mu \mathrm{m}$. Figs. 4 to 7 . Immunohistochemical staining of paraffin sections. Fig. 5. Section of spinal cord stained immunohistochemically (arrows) after IM injection (Day 2 p.i.). Scale bar $=10 \mu m$. Fig. 6. Retina stained immunohistochemically after IM injection (Day 4 p.i.). Note the immunolabeling in the layer of rods and $\overline{c o n e s}(R C L)$, in the outer plexiform layer (OPL) and the inner nuclear (INL) layer (arrows). Note also the absence of lesions in this part of the retina in contrast to Fig. 8. IPL: inner plexiform layer; ONL: outer nuclear layer. Scale bar $=10 \mu \mathrm{m}$. Fig. 7 . Brain stained immunohistochemically after IP injection (Day 4 p.i.). Note the immunolabeling limited in the cytoplasm (CY) of neuronal cells (N: nucleus) (arrows). Scale bar $=10 \mu \mathrm{m}$. Fig. 8. Retina stained immunohistochemically after IP injection. Note the conspicuous vacuoles (V) associated with strong immunolabeling (arrows) especially in the outer nuclear layer (ONL) and in the outer plexiform layer (OPL). RCI: layer of rods and cones. Scale bar $=10 \mu \mathrm{m}$

\section{Control group}

None of fish examined in each control group were found to be positive by either IHC or RT-PCR, and no histopathological changes were noted.

\section{DISCUSSION}

No matter what mode of infection was used (oral, IP and IM infection, bath exposure and cohabitation), VER was experimentally transmitted in juvenile sea bass. Furthermore, experimentally induced horizontal transmission in sea bass was demonstrated for the first time. Differences were, however, observed with respect to the onset and extent of clinical symptoms, mortality, histopathological condition and level of viral antigen and RNA.

The first clinical signs of disease, common to many fish diseases, were dark coloration, reduced feeding and alternation of lethargy and hyperactivity (de Kinkelin et al. 1985). Spiral swimming was generally observed, except for fish infected via oral and IP infection. In the last 2 cases, the virus was detected in the brain and retina by IHC and RT-PCR, and characteristic lesions were observed in the form of basophilic cells and necrosis in the brain and often in extensive vacuolation in the retina. Munday et al. (1992) have showed that a typical sign of disease such as a whirling pattern of swimming was always associated with the presence of vacuoles in the central nervous system and in the retina; the lesions were correlated with the appearance of clinical signs. In the same way, a correlation could exist between clinical signs and the extent of lesions. After oral and IP infection, the lesions which were occasionally observed in the spinal cord and brain samples were slight and might be insufficient to affect the equilibrium system of fish and consequently to induce spiral swimming. In support of this hypothesis, lesions observed in brains of fish survivors ( $42 \mathrm{~d}$ p.i.) were only slightly necrotic with few vacuoles, whereas in moribund fish showing abnormal swimming, lesions of the central nervous system always seemed to be more extensive (authors' unpubl. data) than those observed in the present study. Diseased fish with only retinal vacuolation could probably adapt themselves to a state of impaired vision, whereas fish with vacuolation of the entire central nervous system could not easily adapt their behaviour so as to ensure survivals.

The outbreak of disease first appeared in the case of infection via injection (IM and IP). Virus directly introduced into the muscle or peritoneal cavity could gain access to the central nervous system faster than virus placed in the fish environment (water, food, infected fish in the case of cohabitation). The low mortality $(10 \%)$ observed after IP injection could be explained by a nonspecific immune defence in the peritoneal cavity. Bodammer (1986) and several other authors have proved that the peritoneal cavity of fish was a good source of cells for phagocytosis (macrophages, eosinophils and neutrophils): a part of the injected virus may be neutralized by phagocytic cells before it can gain access to the central nervous system. Mori et al. (1991) have successfully produced experimental infection via IP injection in juvenile redspotted grouper; abnormal behaviour appeared 10 to $14 \mathrm{~d}$ after exposure to the virus but mortalities were relatively low (10 to $30 \%$ ). Other experiments will be necessary to understand the difference between IP and IM infection in the onset of the disease (clinical symptoms, mortalities) and to demonstrate, by studying the immune response, the possibility that part of the virus is eliminated in the peritoneal cavity.

The mortality values were different depending on mode of infection and it seems that 2 forms of the disease can be observed. Sweetman et al. (1996) and other authors have also distinguished 2 forms of VER disease: in the acute form, fish show nervous symptoms such as spiral swimming, a daily mortality of $5 \%$ and a cumulative mortality of $60 \%$; in the subacute 
form, the course of the disease was slower (1 mo instead of $1 \mathrm{wk}$ in the case of the acute form), nervous disorders were less severe and daily mortality was $0.5 \%$. In the present study, the IM infection induced an acute-like form of the disease with nervous symptoms, severe lesions and massive mortality within a short time. The other modes of infection (oral contamination, bath exposure and cohabitation) led to a subacute form and they were more closely related to infections occurring naturally under farm conditions.

Characteristic lesions such as basophilic cells, necrosis and vacuolation were only observed in the central nervous system and in the retina. Similarly, virus antigens detected by IHC and nodavirus genome by RTPCR were only found in the brain and the retina of infected fish. Virus was also detected in the spinal cord by IHC. These methods did not detect virus in other organs, indicating either that the organs (gills, heart, spleen, liver, kidney, stomach and intestine) did not carry the virus at the sampling time or that the level of virus was below the detection limit of the techniques used. Some differences were noted between the 2 methods of detecting the virus (Table 2): detection of viral antigen by IHC seems to be more sensitive than detection of viral genome by RT-PCR. Several samples were found to be positive by IHC while they were negative by RT-PCR examination. This result was more often observed in the case of brain samples, which could indicate that the quantity of virus was below the detection limit of the PCR method in these samples or that the virus was in an undetectable form. This could be explained by a slightly lower sensitivity of the RT-PCR when used for the detection of the sea bass virus compared to striped jack nervous necrosis virus (SJNNV) because a few mismatches exist between the coat protein gene sequences of striped jack and sea bass nodavirus (Nishizawa et al. 1997). The sea bass nodavirus isolate was classified as being of the RGNNV (redspotted grouper nervous necrosis virus) type, which has more nucleotide substitutions as compared to the SJNNV isolate. The problem of RTPCR sensitivity can be resolved by the use of sea bass specific primers and/or the use of a nested RT-PCR. In addition, the possibility that there may be a nonspecific immunoperoxidase reaction cannot be totally discounted even if, in this study, the noninfected sections (brain and eye of the control group) showed no reaction with the polyclonal rabbit antiserum. Nevertheless, further studies will be needed to evaluate the sensitivity of the IHC method by testing the specificity of polyclonal antiserum and the use of different fixatives. Skliris et al. (1996) showed that formalin fixedtissues demonstrated reduced antigenicity compared to bouin-fixed tissues, and this is why Bouin's fixative was used here in preference to buffered formalin.
The retina seems to be a target tissue for nodavirus (Fig. 1). This hypothesis is based on several observations: on the one hand, IHC intensity increased in the retina with the sampling time whereas a reduction or a stabilization was noted in brain samples and the lesions were also more extensive in the retina than in brain and spinal cord of the same fish. On the other hand, viral genome detection by RT-PCR was more often positive in retina samples than in the brain, which probably indicates that this tissue was strongly infected. Necrosis of the nerve cells and vacuolation were often very pronounced in the retina especially in the inner nuclear and ganglionic cell layers. Focal aggregates strongly stained by $\mathrm{H \& E}$ and $\mathrm{IHC}$ were seen in these layers but only $42 \mathrm{~d}$ p.i. These structures could not be clearly identified by histopathological observations alone. In the observed sections, they seemed to consist of several cells which could be retinal cells affected by virus and in the process of becoming necrotic. After total destruction, these focal aggregates may give way to large vacuoles.

The virus was only seen in the central nervous system and in retina, confirming the neurotropism of the nodavirus (Table 2, Fig. 1). Nguyen et al. (1996) suggested that one of the initial multiplication sites of the virus in larval striped jack was the spinal cord just above the swimbladder; then the virus spread backward to the end of spinal cord and forward to the brain to terminate in the retina probably via the optic nerve. Virus may gain access to the central nervous system via the peripheral nervous system, which is composed of nerves which emerge from the brain and spinal cord. After oral and IP infection, viscerosensory and visceromotric fibers connecting the sensory and effector organs of the viscera with the central nervous system may be used by the virus to reach first the brain and then the eyes of the fish. Even if there is no detectable virus in the other organs, virus must be present somewhere before its apparent multiplication in the nerve cells, either in an undetectable form or at an undetectable level. Arimoto et al. (1992) detected the virus in the ovaries of striped jack spawners and in fertilized eggs. Nguyen et al. (1997) observed that the virus was present not only in the gonad but also in the intestine, stomach, kidney and liver of 13 yr old striped jack; according to them, during the stress of spawning, the virus replicates and is distributed in all these organs.

The portals of entry of the virus were not identified here after bath exposure and cohabitation. No virus was detected in gills of infected fish by IHC or RT-PCR analysis, but these organs were not examined before Day 4 p.i. Nguyen et al. (1996) reported that virus multiplication was observed in the epidermal cells of striped jack larvae, which could promote horizontal 
transmission, but in the opinion of the authors the role of skin as a portal of entry still remains unclear even if the virus is able to enter the spinal cord via sensory and/or motor nerve cells linked to the epithelium.

Le Breton et al. (1997) noted that all sizes of cultured sea bass must be considered sensitive to the nodavirus. According to Arimoto et al. (1992), juvenile striped jack were not sensitive to the virus after bath exposure in a purified viral solution of $100 \mathrm{ng} \mathrm{m}^{-1}$. Neither significant mortality nor abnormal behaviour was observed during the $4 \mathrm{wk}$ of the experiment while under the same conditions larvae developed the disease. The massive mortality caused by nodaviruses seems to occur especially in the larval stage, but in Epinephelus septemfasciatus (Fukuda et al. 1996, Tanaka et al. 1998) and sea bass (Bellance \& Gallet of Saint Aurin 1988) as well, disease leads to nonnegligible mortality in the juvenile and more developed stages. Age could certainly affect the susceptibility of fish to the VER. The maturity of the immune system could perhaps partly explain the differences in mortality values between larvae and juveniles. The lymphoid system is not fully mature at hatching; indeed, the larvae have to rely mainly on nonspecific defence mechanisms such as phagocytosis or perhaps, for specific defence, on maternal immunity. Further studies will be needed to evaluate the immune response of fish to the infection.

The results obtained during this experimental transmission show that juvenile sea bass weighing $3 \mathrm{~g}$ are susceptible to the nodavirus. Subsequently, we assume that horizontal transmission, the existence of which is strongly suspected based on observations in the field, occurs under natural conditions where healthy fish cohabite with carriers. The cannibalistic behaviour of young fish could be also a means of VER transmission: during our experiments, fish tended to eat the viscera and eyes of dead fish, which could have contained the virus

The aim of this study was to refine an experimental model of VER transmission in juvenile sea bass. Two modes of infection will be chosen for further experimental models: intramuscular injection to evaluate the viral dose effect and bath exposure to study the entry and tropism of the virus

Acknowledgements. We thank Dr M. Comps and Dr G. Breuil for kindly providing the anti-nodavirus serum.

\section{LITERATURE CITED}

Arimoto M, Mushiake K, Mizuta Y, Nakai T, Muroga K, Furusawa I (1992) Detection of striped jack nervous necrosis virus (SJNNV) by enzyme-linked immunosorbent assay (ELISA). Fish Pathol 27(4):191-195
Arimoto M, Mori K, Nakai T, Muroga K, Furusawa I (1993) Pathogenicity of the causative agent of viral nervous necrosis disease in striped jack, Pseudocaranx dentex (Bloch \& Schneider). J Fish Dis 16:461-469

Arimoto M, Maruyama K, Furusawa I (1994) Epizootiology of viral nervous necrosis (VNN) in striped jack. Fish Pathol 29(1):19-24

Bellance R, Gallet de Saint-Aurin D (1988) L'encéphalite virale du loup de mer. Caraibes Médical, p 105-114

Bloch B, Gravningen K, Larsen JL (1991) Encephalomyelitis among turbot associated with a picornavirus-like agent. Dis Aquat Org 10:65-70

Bodammer JE (1986) Ultrastructural observations on intraperitoneal exudate cells from the striped bass. Vet Immunol Immunopathol 12:127-140

Boonyaratpalin S, Supamattaya K, Kasornchandra J, Hoffmann RW (1996) Picorna-like virus associated with mortality and a spongious encephalopathy in grouper Epinephelus malabaricus. Dis Aquat Org 26(1):75-80

Breuil G, Bonami JR, Pépin JF, Pichot Y (1991) Viral infection (picorna-like virus) associated with mass mortalities in hatchery-reared sea-bass (Dicentrarchus labrax) larvae and juveniles. Aquaculture 97:109-116

de Kinkelin P, Michel C, Ghittino P (1985) Virus et virioses. In: INRA-OIE (eds) Précis de pathologie des poissons. INRAOIE, Paris, p 65-94

Frerichs GN, Rodger HD, Peric Z (1996) Cell culture isolation of piscine neuropathy nodavirus from juvenile sea bass, Dicentrarchus Labrax. J Gen Virol 77:2067-2071

Fukuda Y, Nguyen HD, Furuhashi M, Nakai T (1996) Mass mortality of cultured sevenband grouper, Epinephelus septemfasciatus, associated with viral nervous necrosis. Fish Pathol 31(3): 165-170

Gabe M (1968) Techniques histologiques. Masson, Paris

Glazebrook JS, Heasman MP, de Beer SW (1990) Picorna-like viral particles associated with mass mortalities in larval barramundi, Lates calcarifer Bloch. J Fish Dis 13:245-249

Grotmol S, Totland GK, Kvellestad A, Fjell K, Olsen AB (1995) Mass mortality of larval and juvenile hatchery-reared halibut (Hippoglossus hippoglossus L.) associated with the presence of virus-like particles in vacuolated lesions in the central nervous system and retina. Bull Eur Assoc Fish Pathol 15(5):176-180

Le Breton A, Grisez L, Sweetman J, Ollevier F (1997) Viral nervous necrosis (VNN) associated with mass mortalities in cage reared sea bass Dicentrarchus labrax. J Fish Dis 20:145-151

Mori KI, Nakai T, Nagahara M, Muroga K, Mekuchi T, Kanno $T$ (1991) A viral disease in hatchery-reared larvae and juveniles of redspotted grouper. Fish Pathol 26(4):209-210

Mori KI, Nakai T, Muroga K, Arimoto M. Mushiake K, Furusawa I (1992) Properties of a new virus belonging to nodaviridae found in larval striped jack (Pseudocaranx dentex) with nervous necrosis. Virology 187:368-371

Munday BL, Langdon JS, Hyatt A, Humphrey JD (1992) Mass mortality associated with a viral-induced vacuolating encephalopathy and retinopathy of larval and juvenile barramundi, Lates calcarifer Bloch. Aquaculture 103: $197-211$

Nguyen HD, Nakai T, Muroga K (1996) Progression of striped jack nervous necrosis virus (SJNNV) infection in naturally and experimentally infected striped jack Pseudocaranx dentex larvae. Dis Aquat Org 24:99-105

Nguyen HD, Mushiake K, Nakai T, Muroga K (1997) Tissue distribution of striped jack nervous necrosis virus (SJNNV) in adult striped jack. Dis Aquat Org 28:87-91

Nishizawa T, Mori KI, Nakai T, Furusawa I, Muroga K (1994) 
Polymerase chain reaction (PCR) amplification of RNA of striped jack nervous necrosis virus (SJNNV). Dis Aquat Org 18:103-107

Nishizawa T, Furuhashi M, Nagai T, Nakai T, Muroga K (1997) Genomic classification of fish nodaviruses by molecular phylogenetic analysis of the coat protein gene. Appl Environ Microbiol 63(4):1633-1636

Office International des Epizooties (1995) Viral encephalopathy and retinopathy. In: OIE (ed) Diagnostic manual for aquatic animal diseases. OIE, Paris, p 85-90

Renault T, Haffner P, Baudin Laurencin F, Breuil G, Bonami JR (1991) Mass mortalities in hatchery-reared sea bass (Lates calcarifer) larvae associated with the presence in the brain and retina of virus-like particles. Bull Eur Assoc Fish Pathol 11:68-73

Skliris G, Richards RH, Frerichs GN, Rodger HD (1996) Piscine neuropathy nodavirus in naturally infected seabass (Dicentrarchus labrax). Histological and immunohistochemical evaluation. Seabass and seabream culture:

Editorial responsibility: Jo-Ann Leong,

Corvallis, Oregon, USA problems and prospects. European Aquaculture Society, Verone, October 16-18, p 316-319

Sweetman E, Sweetman J, Le Breton A, Grisez L (1996) Nodavirus: a review of the findings of XIV/noda/95 investigation. Seabass and seabream culture: problems and prospects. European Aquaculture Society, Verone, October 16-18, p 87-101

Tanaka S, Aoki H, Nakai T (1998) Pathogenicity of the nodavirus detected from diseased sevenband grouper Epinephelus septemfasciatus. Fish Pathol 33(1):31-36

Thiéry R, Peducasse S, Castric J, Le Ven A, Jeffroy J, Baudin Laurencin $F$ (1997) Experimental transmission of viral encephalopathy and retinopathy to juvenile sea bass (Dicentrarchus labrax). Bull Eur Assoc Fish Pathol 17: $118-122$

Yoshikoshi K, Inoue K (1990) Viral nervous necrosis in hatchery-reared larvae and juveniles of Japanese parrotfish, Oplegnathus fasciatus (Temminck \& Schlegel). J Fish Dis $13: 69-77$

Submitted: April 5, 1998; Accepted: October 28, 1998 Proofs received from author(s): April 6, 1999 